\title{
A template for the audio introduction of operas:
}

\section{A proposal}

\author{
GONZALO ITURREGUI GALLARDO \\ Iris Cristina Permuy HérCules de SolÁs \\ gonzalo.iturregui@uab.cat \\ iris.permuy@uab.cat \\ Universitat Autònoma de Barcelona
}

Fecha de recepción: 5 de enero de 2019

Fecha de aceptación: 15 de octubre de 2019

Abstract: Audio Introductions (Al) consist of a brief description of the plot, history and technical aspects of an audiovisual product and are generally presented at the beginning of an operatic event. Despite their prevalence, literature related to the elaboration of $A I$ in audio description (AD) guidelines is scarce. Continuing the investigation carried out by the research group Transmedia Catalonia in the field of AD for opera, this article focuses on the role of Al in opera, not only as an access service for the blind and visually impaired audience, but also for all audience members.

Furthermore, a template for Als is put forward, in which the contents that Als should cover for the appropriate presentation of the information relevant to the opera are detailed and explained. The article delves into these contents and underscores their importance for enhancing the experience of the opera for both the visually impaired and the general audience. The creation and distribution of a template draws attention to the potential of standardisation of this access service.

The article is based on the analysis of a template used at the Gran Teatre del Liceu of Barcelona by the audio describer, also a co-author of the article, employed in the production of Als throughout the opera season 2016/17. The creation of Als by means of the template improved the workflow by providing a clear understanding of the topics to be covered beforehand and by outlining the time constraints during the live performance on the contents.

Keywords: Media Accesibility, Audiovisual Translation, Opera, Audio Introduction, Audio Description

Resumen: Resumen: Las audiointroducciones (Al) consisten en una breve descripción del argumento, la historia y los aspectos técnicos de un producto audiovisual y generalmente se encuentran al principio de los eventos operáticos. A pesar de su uso frecuente, poco se ha escrito sobre la elaboración de Al para audiodescripción (AD). En línea con la investigación 
llevada a cabo por el grupo de investigación Transmedia Catalonia en el campo de la audiodescripción para ópera, este artículo trata el papel de la Al para ópera no solo como servicio de accesibilidad para personas ciegas o con baja visión sino también como recurso para todo tipo de público. Se propone, además, una plantilla para Al en la que se explican y detallan los contenidos que una Al debería tener para una adecuada presentación de la información relevante de la ópera. Este artículo analiza estos contenidos y remarca la importancia que tienen a la hora de mejorar la experiencia operática tanto para el público ciego o con baja visión como para el público general. La creación y distribución de esta plantilla pone de relieve el potencial de estandarización de este servicio de accesibilidad. El artículo se basa en el análisis de una plantilla utilizada por el audiodescriptor, también coautor del artículo, en el Gran Teatre del Liceu de Barcelona para la producción de Al durante la temporada de ópera 2016/17. La creación de Al a través de esta plantilla mejoró el ritmo de trabajo ya que ofrece una visión clara de los temas que se deben tratar y de las restricciones de tiempo que afectan a los contenidos durante las funciones en directo.

Palabras clave: Accesiblidad a los medios audiovisuales, Traducción audiovisual, Opera, Audiointroducción, Audiodescripción

\section{AUDIO DESCRIBING OPERA}

The service of Audio Description (AD) provides accessibility for very different audiovisual contents. This first section aims to introduce the service and explore its application to live audiovisual events, such as opera. AD is an oral commentary based on an intersemiotic translational technique used to overcome the barriers encountered when audiences with specific needs, such as the blind and the visually impaired, consume an audiovisual product. It stands as a way of mediation which is "cross-modal, involving essentially a 'translation' of visual images into verbal text" (Braun 2008: 2). The description of the visual input "fits in the silences between dialogues and describes action, body language, facial expressions and anything that will help people with visual impairment follow what is happening on screen or stage" (Díaz Cintas \& Anderman 2009: 8). This form of aural adaptation has proved very effective. In fact, studies on mental imagery - the capacity of creating images in the mind - have shown that this capacity is not only related to the ability of seeing. Essentially, people with vision loss can recreate images when exposed to the aural stimuli presented through AD (Fryer 2010; Pylyshyn 2002).

$A D$ can be traced back as far as the Medieval Ages, when pilgrims needed oral explanations to understand and enjoy the visual narrative in the 
stained glass windows of churches and cathedrals (Benecke \& Dosch 2004; Pujol \& Orero 2007). According to Ramos Caro (2016), the origins of AD as conceived in modern times are found in the 1940s, when the first films were described on Spanish radio after the Spanish civil war. Currently this service is offered around the globe, both from associations for the blind and from governments and broadcasters, and has become available in an increasing number of countries in the last 20 years (Fryer \& Freeman 2013; Orero $2007 \mathrm{~b}$ ). As a result of its steadily growing presence in modern audiovisual production, the academic study of AD within the framework of Audiovisual Translation and Media Accessibility Studies has attracted interest in recent decades (Fryer, 2016; Igareda \& Matamala, 2012; Kruger \& Orero, 2010) particularly within the field of cinematographic production. However, other kinds of audiovisual media such as opera, theatre or other forms of performing arts have also benefitted from this technique, in an effort to be inclusive to wide audiences.

Many standards and guidelines on media accessibility include $A D$ (see AENOR 2005; Benecke \& Dosch 2004; Independent Television Commission (ITC) 2000) as a description placed in silent moments or when there is only background music during an audiovisual product. The implementation of $A D$ in performing arts, though, is more complex, for they present specific challenges, the most prominent being the live aspect (Matamala 2007). This means that each individual performance can differ, particularly in terms of timing and structure. This kind of $A D$ for live events is voiced live by the narrator, normally also the audio describer.

Due to these constraints, sometimes AD is unable to cover all the visual information appearing on screen or stage. The information may then be imparted in the form of audio introductions (Al), as it is usually done before an opera or theatre performance, or before each act or section. Al as a technique for conveying information as a part of the AD service has not been studied in depth as of yet with only a handful of articles on the topic (Di Giovanni 2014; Hammer et al. 2015; Jankowska 2013; Remael \& Reviers 2013; Reviers 2014; Romero-Fresco \& Fryer 2013).

The present article focuses on opera and its intrinsic characteristics. This medium can easily benefit from Als due to the amount of information to be conveyed in the AD: what is happening on stage, the information provided by the surtitles and/or subtitles and, ideally, a summary of the contents in the libretto or leaflet (Matamala, 2005). The amount of information, combined with a rarity of silent gaps, make the AD of opera a very demanding task. In order to cover the information which may be lost due to all these limitations, an introduction before the opera play or before every act has the potential to be very helpful for audiences with sight loss. Als stand as a form of descriptive 
prologue, and as in cinema, they consist of "a continuous piece of prose providing factual and visual information about the source material that must engage the listener's attention [and] whet their appetite" (Romero-Fresco \& Fryer 2014).

This article discusses the creation of a template for the implementation and delivery of opera $\mathrm{Al}$ which will form a common structure to meet the informative needs of visually impaired opera goers. The template is proposed based on the experience of the audio describer, Iturregui-Gallardo, co-author of this article, who created the Al scripts and voiced them live introducing the $A D$. This initiative adds to previous research carried out in the framework of the Gran Teatre del Liceu of Barcelona, which has become a research hotspot in the field of performing arts accessibility thanks to a Memorandum of Understanding between this opera house and the research group Transmedia Catalonia.

As one of the most important theatres in the country, the Gran Teatre del Liceu of Barcelona has introduced important technological changes which have improved its accessibility services, especially since 1994 when a fire caused extensive damage to the building. The reconstruction works provided an opportunity to implement a series of technological improvements in its subtitling, surtitling and media accessibility services (Matamala \& Orero, 2007). The research group Transmedia Catalonia has played a leading role in the studies concerned with opera accessibility in Spain, particularly thanks to the relationship between this opera house and the university. By taking the literature produced by its scholars on AD for opera as a starting point, the following paragraphs aim to situate Als and their characteristics within the research field.

As a live event, opera $A D$ presents specific challenges. Matamala analyses the types of live $A D$ that exist (2007) and the challenges faced by professionals when implementing them. She focuses on the Catalan scene (2005), paying special interest to opera performances. During the same years other studies were published solely devoted to the AD used in opera. Orero and Matamala (2007) present an overview of the application of subtitling and surtitling services to overcome the language barrier, as well as of $A D$ services in opera. By taking one step further in accessibility for opera, the same research group tested an audio subtitling service which was able to read aloud written subtitles and surtitles (Orero, 2007a). In this case study, the interlinguistic translation surtitles and subtitles from the original language into Catalan was made available for blind and visually impaired audiences by means of audio subtitles. Their implementation was generally well received by end users. However, it is to be noted that, as the technique is characterised by the overlapping of the original musical pieces and the read-aloud 
translation, the individual preference towards a more musical-centred experience or a more textual-centred experience of each user can affect how well it was received.

\section{AUDIO INTRODUCING OPERA}

Nowadays, some opera houses and theatres across the globe -other than the Gran Teatre del Liceu- offer audio-described sessions for people with specific needs. Such is the case of the Opera North, in Nottingham; the Royal Opera House and the English National Opera established in the London Colisseum, both in London; the Spanish Teatro Real in Madrid; the Sferisterio di Macerata, adapted as opera house during the Macerata Opera Festival; or the Ópera National de Paris.

Some of these venues also provide the service of Al. These Als are available for downloading directly from their webpages (see, for example, the Als for the Royal Opera House and The English National Opera ${ }^{1}$ or the Macerata Opera Festival ${ }^{2}$ ) or are performed live before the beginning of the opera (as in the Ópera National de Paris). The way the Als are produced varies across the opera houses. During the Macerata Opera Festival, Als can be found on its webpage and last from 5 to 10 minutes per opera. In the Royal Opera House or the English National Opera, the pre-recorded Als, apart from being available for downloading them from the webpage are played repeatedly during the 15 minutes before the opera. In Paris, not all operas contain an Al, but if it is provided, this is done live before the beginning of the opera. The form and presentation of these Als are different depending on the characteristics and needs of the venue, opera performance and delivery to the audience. This article proposes a template adapted to the Liceu opera house's reality, but it can serve as a model that could be reproduced.

The outcomes and conclusions of previous research in this Catalan opera house led to new approaches to opera AD. Cabeza and Matamala (2008), in their proposal for the AD of opera performances, introduce the $\mathrm{Al}$ as a way of conveying information before the performance and its various acts. Their chapter mentions the possibilities of such audio excerpts, which can be uploaded online and made available for sighted audiences as well. These Als condense the information regarding not only the plot of the opera but the libretto and the historical and technical aspects of the opera in three different languages. Two years later, in the case study of the opera Andrea Chénier, Cabeza (2010) analyses the implementation of two types of AD for

\footnotetext{
${ }^{1} \mathrm{http} / / /$ www.sightlines-audio-description.com/audio-introductions

${ }^{2}$ https://www.sferisterio.it/en/accessibility
} 
opera: an $\mathrm{Al}$ combined with a comprehensive $\mathrm{AD}$ avoiding overlapping with the singing, and an extensive Al with no AD during the performance. The study found that users preferred the use of an $\mathrm{Al}$ complementing the $\mathrm{AD}$ during the performance. Corral \& Lladó (2011) analyse the AD model for opera established after previous research by the Transmedia Catalonia group and comment on the application of such an AD model for Szymanowski's opera Król Roger and detail the best use of AD techniques in opera.

Beyond academia, the benefits of audio introductions have been discussed by different professional audio describers. Notably, Greg York shared his 40-year long experience in opera and ballet $A D$ at the English National Opera and Royal Opera House. He highlights the importance of the Al resource, which he refers to as "Talking Notes", as a means for "uninterrupted enjoyment of the performance" (York, 2007: 215) for the visually impaired. In his recommendations on how to issue and deliver an Al, he provides a list of items to be included, namely: essential credits, nutshell synopsis, production concept -sets and costumes, scene sympathy, shapes, textures and colours.

York's recommendations are also considered in Puigdomènech, Matamala \& Orero (2008) with the aim of creating guidelines for Catalan opera $A D$. They consider the inclusion of Als in events where the information is to be given before and not during the event. Even though the article mentions the many aspects that the AD should cover, namely characters, stage, actions and so forth, and how these aspects should be delivered, the Al is not explored in detail. However, these scholars examine the differences between opera events (live or recorded, with or without breaks) and how the information to be provided can be distributed in each case, thus underlining the importance and utility of the Al strategy.

Having said that, and despite York's work on Al, there are currently no guidelines for the creation of Als for opera, although some opera houses stick to the same internal model (e.g. The Royal Opera House in London or the Macerata Opera Festival). Having detected the lack of literature in the matter, this article presents a template for opera Al at the Liceu theatre in Barcelona. It stands, then, as a first step towards the creation of guidelines and ultimately the standardisation of opera Al. This final goal can be reached through more research and end user testing. Although standardisation could also entail some drawbacks, such as the fact that Al could be perceived as monotonous or with a lack of creativity, the template only aims at structuring and limiting the contents so as to fit timings in a live opera event and facilitate the work of the audio describer. Therefore, it is not a strict and fixed proposal, but a skeleton from which contents can adapt to the specific operatic event and venue. 


\section{RATIONALE}

While some standards and guidelines provide guidance for the creation of $A D$, neither the function nor the incorporation of $A I$ in different kinds of audiovisual contents have been treated in depth yet. Similarly, in standards and guidelines few is said about other long-established opera accessibility services, such as surtitling. Surtitle form and functioning is dictated by previous research based on aspects such as reading speed or text positioning (Burton 2008; Eardley-Weaver 2014; Griesel 2005; Mateo 2007; Palmer 2013; Wijnants 2014). Also, surtitles are launched with the help of specialised computer programs. Meanwhile, live human-voiced Al presents a handcrafted nature. The details to be included are not regulated by any convention or software, but rather time limitations, and the content decision-making is to be faced by audio describers.

Taking all of the above into consideration, the creation of a template for Al found its rationale in a series of common unmet needs. For each of the operas played on the Liceu's stage, Transmedia's research group is in charge of providing the live $A D$ for the accessible session. Apart from preparing an $A D$ script to be narrated to the audience, each of the operas had to be introduced before the beginning of the event. While some of the operas, such as Macbeth or La Fille du Régiment, presented a more traditional mise-enscène, others, such as Quartett or The Magic Flute, combined more innovative particularities, such as unusual stage designs and video projections. The latter may require further information, making the $\mathrm{Al}$ almost an indispensable part of the experience. Thus, it can be argued that the form and the structure of an Al will depend heavily on the particularities of the audiovisual product being audio described. As previously mentioned, operas differ greatly even among the different productions of the same oeuvre. However, the application of a skeleton from which the various pieces of information can be hung could perform the following functions:

- provide cohesion amongst performances;

- standardise Al structures so users will know what to expect;

- convey the information in a more concise way to speed-up the work of the audio describer when producing Als;

- and make circulation and exchange of the Als across languages more agile if the operas tour across different territories.

Primarily, following a pre-determined template will provide cohesion throughout all the Als provided by the same theatre, in our case, the Gran Teatre del Liceu. Over the years this opera house has cultivated a corporate identity which includes among other things a series of symbols, logos and 
product design (found in its leaflets, website and brochures) which audiences associate with the theatre. Als could become another item in this corporate identity, an extra service that the users can expect in every performance.

Secondly, it will aim for clarity and ease of use with its customers, since consistently providing similarly structured Als in each audio described event offered by the opera house will familiarise the user with the information provided by the $\mathrm{Al}$, its duration and structure. Depending on their experience with the opera house, they would be able to predict the amount of information available in the Al and look for more in-depth details beforehand if they so desire.

At the opera house of Liceu, every operatic performance is accompanied by a vast amount of textual information included in the programme and brochure. Such information does not only concern details about the production itself, but also interpretations and analyses provided by different scholars or other opera musicologists or historians. A template will provide guidance in terms of how much information is to be conveyed, therefore ensuring the successful condensation of information and streamlining the creation of the $\mathrm{Al}$ itself.

Finally, the use of guidelines will contribute to the standardisation of such introductory pieces of information and foster the circulation and exchange of Als across opera houses. It will save some work and provide internal harmony, create expectations in the audience and avoid bad or incomplete introductions. Opera performances held in the Barcelonan opera house are big productions created with large budgets that normally go on tour to different theatres. A template like the one proposed here would avoid the repetition of the research step and the task of discriminating the relevant information. This would be true not only for the reproduction of the $\mathrm{Al}$ in other performances, but also its translation into other languages.

\section{THE CREATION OF A TEMPLATE FOR THE AUDIO INTRODUCTION OF OPERAS}

By means of questionnaires, Fryer and Romero (2013) illustrate how Als can enhance visually impaired audiences' access to screen media by contributing additional cinematic and other visual information. We argue that the same can be true for live performances such as opera. Thus, following Romero-Fresco and Fryer's proposal of an Al for Quentin Tarantino's motion picture Inglourious Basterds (2014a), and adapting it to the specific needs of opera, we have designed a template for opera Al within the framework of the 2016/2017 season. 
This comprehensive template aims to summarize the most relevant aspects of an opera that may go unperceived for visually impaired audiences. It includes not only the obvious visual description of the stage, but also the details usually appearing in the libretto, which is not always accessible by means of braille or an audio guide. It also covers aspects of the visual style or the intertextual references that might go unnoticed even by sighted audiences.

As stated by Reviers (2014), the possible functions of an Al are informative, foreshadowing, expressive-aesthetic, and instructive, which she defines as follows:

a) Informative: information about the most factual data is provided; namely, the director, the cast, the running time of the opera, its synopsis, etc.

b) Foreshadowing: information about the characters and their wardrobe or makeup is also provided, aiming to ease their identification during the opera. Furthermore, when audio introducing the characters it is recommended that a brief recording of each of the actor's voices is included, where possible. In this way, the blind or visually impaired audience members are able to easily recognize which character is speaking at any given moment.

c) Expressive-aesthetic: this includes the visual techniques used on stage. Apart from the narrated information, the tone of the Al itself should be considered. The Al should set the opera's mood, or at least not conflict with it, be it sad, heroic, romantic, etc. as suggested by some studies on $A D$ intonation which suggest departing from a neutral intonation in certain audiovisual genres (see Walczak2017; Walczak \& Fryer 2017; forthcoming).

d) Instructive: the most practical pieces of information about the theatre venue and the technical aspects of the Al/AD service.

The order in which all this information appears is based upon Reviers' recommendations (2014) found in the AD ADLAB guidelines (Remael, Reviers, \& Vercauteren, 2014), as detailed below:

- Begin with a welcome word, present yourself/the speaker and relate the running time of the introduction;

- Begin with factual details and include more descriptive elements at the core of the introduction;

- Combine the description of the plot and characters, as it helps to remember characters when they are placed in a narrative;

- End with the instructive function, if there is one. 
Reviers' assertions were considered in the creation of the template. In the following section the items that are to be included in this template for Al for opera are presented and accompanied by a sample of the contents.

\section{A PROPOSAL FOR AN AI TEMPLATE}

The template for Al of opera proposed in this article based upon the available literature on the subject and put into practice by the audio describer during the season $2016 / 17$. The creation of a template is born out of the audio describer's needs, who had a limited time for the delivery of the Al before the opera started and received multiple sources of information that were to be summarised. The limitation of time made the audio describer had to choose on the contents to include in the Al. Since the informative materials about each opera follow the same pattern and thus, the same kind of information and organisation, some key points were selected to develop in the Al.

Therefore, the contents in the template are based on previous research and proposals on Al and then materialised from the audio describer's needs when dealing with all the information provided on the operatic event to be audio described. All the aforementioned aspects are tackled as follows (Table 1): 


\begin{tabular}{|c|c|}
\hline TYPE OF ITEM & CONTENTS \\
\hline $\begin{array}{l}\text { Audio introduction } \\
\text { presentation }\end{array}$ & $\begin{array}{l}\text { Good evening, my name is [insert audio describer's name] } \\
\text { and today I will accompany you during the audio } \\
\text { description and audio introduction of the opera [insert } \\
\text { name of the opera], [genre of the opera: melodrama, } \\
\text { tragicomedy, etc.] in [number] acts, by [name of the } \\
\text { composer]. }\end{array}$ \\
\hline $\begin{array}{l}\text { Opera introduction (title, } \\
\text { name of the director and } \\
\text { compositor, date of release, } \\
\text { duration) }\end{array}$ & $\begin{array}{l}\text { This opera was composed by [insert composer]. The } \\
\text { libretto was written by [name of the librettist]. - } \\
\text { Information about previous collaborations between } \\
\text { composer and librettist. } \\
\text { - Renowned pieces by the librettist. } \\
\text { This performance is directed by [insert director] and: } \\
\text { a) is a production of [name of the institution/producer] } \\
\text { b) is a co-production of the [name of the } \\
\text { institutions/producers] } \\
\text { This performance was premiered on [date] at [insert opera } \\
\text { house/theatre]. }\end{array}$ \\
\hline Background information & $\begin{array}{l}\text { - Historical context } \\
\text { - Special features of the genre } \\
\text { - Compositor's biographical and professional circumstances } \\
\text { at the time of creation and performance of the opera } \\
\text { - Anecdotes of the release, specifications of the theatre } \\
\text { itself } \\
\text { - Release and public reception at this specific opera house } \\
\text { and total number of performances (if performed in the } \\
\text { past) }\end{array}$ \\
\hline $\begin{array}{l}\text { Other aspects that might need } \\
\text { explanation }\end{array}$ & [For example, intertextual references] \\
\hline $\begin{array}{l}\text { Characters and a cast } \\
\text { summary. If possible, insert a } \\
\text { little extract of the main actors } \\
\text { singing voices as well }\end{array}$ & $\begin{array}{l}\text { The main characters are: } \\
\text { - [Insert name of character], portrayed by [nationality] [or } \\
\text { city when talking about national singers] [voice category] } \\
\text { [insert name of actor] }\end{array}$ \\
\hline $\begin{array}{l}\text { Wardrobe and makeup } \\
\text { descriptions if relevant }\end{array}$ & $\begin{array}{l}\text { This section can be intertwined with the characters' } \\
\text { descriptions: } \\
\text { - [Name of the character] is wearing a [colour, texture, etc. } \\
\text { garment/piece of clothing] and has [description] [hairstyle, } \\
\text { make-up specificities] }\end{array}$ \\
\hline Synopsis & $\begin{array}{l}\text { Brief synopsis of the whole opera. It has to be taken into } \\
\text { account that more in-detail summaries of acts/parts are } \\
\text { also provided. }\end{array}$ \\
\hline $\begin{array}{l}\text { Locations, scenery and visual } \\
\text { style }\end{array}$ & $\begin{array}{l}\text { - Divisions of the stage } \\
\text { - Changes in the set } \\
\text { - Curtain work } \\
\text { - Lighting } \\
\text { - Other relevant details concerning scenery and decoration. }\end{array}$ \\
\hline Practical information| & $\begin{array}{l}\text { - Timing and pauses } \\
\text { - Any other practical aspects relevant to the performance } \\
\text { The opera has a running time of [insert duration of opera] } \\
\text { minutes. The first part, of [number of minutes] is followed } \\
\text { by a [number of minutes] break. Act[s] [numbers] will be } \\
\text { performed in the [second, third, etc.] part. }\end{array}$ \\
\hline
\end{tabular}

Table 1. Contents of the audio introduction

Hikma 18 (2) (2019), 217 - 235 
Special attention should be paid to the suggestion to include a short recording of the main actors singing voices when introducing them. This would allow visually impaired spectators to recognize the characters as they appear on stage. Further, Reviers' structure is not strictly followed, with slight modifications based on the researchers' personal experience at the Grand Teatre del Liceu. A real example of this experience is provided in the next section.

\subsection{Example of an opera audio introduction for the Gran Teatre del Liceu}

With the aim of testing this template, an Al was issued following the template for the opera Macbeth by Giuseppe Verdi (Table 2), co-produced with the Grand Théâtre de Genève and performed in the Gran Teatre del Liceu from 7th to 23rd October 2016. The opera session offered with the AD service (including the Al) was staged with on 19th October 2016.

\subsubsection{Putting the template into practice}

Since the beginning of the 2016/2017 season, all the Als preceding the AD for each of the audio described operas performed at the Grand Teatre del Liceu were issued by following the template. The Liceu offers one live audio described performance for every production that is staged. To date, 11 operas have been audio introduced through this method. The personal experience of the audio describer, who was also the narrator (co-authoring this article), has been positive. The Al and the AD was performed live from one of the studios in the opera house. The audio describer and narrator delivered the contents of the description through a microphone. The AD was received by the blind and visually impaired audience by means of headphones provided before the opera starts, that were plugged in the special plugs with which some of the seats are equipped.

Having a template for these Als that can be reproduced makes the task easier and faster for the audio describer. The template has also improved the process in the following aspects:

- Unification: before the performance, the opera house provides the audio describer with the leaflet of the opera and the official brochure issued for Liceu members. Both documents present a common corporative image and have a consistent structure and way of presenting the information. A template specifying the contents to be present in the Al helps the audio describer to identify and extract the needed information found in both the leaflet and the brochure.

Table 2. Macbeth audio introduction

Hikma 18 (2) (2019), 217 - 235 
- Time and space: the identification of the topics to be treated in the $\mathrm{Al}$ in advance is essential when managing the time the audio describer has for the live narration of the Al. This has allowed for better timed $\mathrm{Al}$, that suits the time constraints posed by the live genre. Every opera house has its own practices. In the case of the Liceu, three pre-recorded notices are delivered to the audience before the beginning of the opera. The notices typically ask audience members to switch off their phones, inform them of the remaining time before the beginning of the performance and are played in three languages. Being aware of the time it takes to read aloud each of the parts of the $\mathrm{Al}$ certainly helps avoid any overlapping of the audio describer's words and the notices delivered through the speakers inside the theatre.

- Translation and transfer: during the 2016/2017 season, the Gran Teatre del Liceu carried out different trials for the improvement of its accessibility mobile phone app (Orero et al., forthcoming). Some members of the research group were involved in the creation of the materials, both written and voicerecorded, for the trials. Als for the operas, Werther and The Magic Flute were required in three different languages: Catalan, Spanish and English. The template was an aid when writing and translating the $\mathrm{Al}$ as it allowed the different texts to respect the space and time constraints. Further, it provided consistency within the app trials and its future commercial running.

\section{CONCLUSIONS}

As stated by Di Giovanni (2014), given "the flexible nature of $\mathrm{Al}$, its relatively simple and not too costly production, its stand-alone nature, which allows for fruition any time before (or even after) a film is viewed, and, last but not least, its audience-reaching potential", it is worth researching and leveraging this service. One possibility is to standardise it, to optimise the limited time available for Al before each opera production or act. A standard of Al could assure that the most important, useful and enjoyable information is available for blind and visually impaired opera lovers. However, it is important to highlight the fact that not only the visually impaired can take advantage of these selected extra details. The information provided in Al, as has been stated before, is summarized from various sources, some of which are available and easily accessible to the public, and some are wordier and more specialised. Therefore, this Al, duly recorded, can be uploaded to the 
website of the opera house accompanying the presentation and plot of the opera performance, so sighted people can also listen to this service and learn more about the opera in which they are about to delight.

This template indicates the possibility of standardizing the production of the Al for opera. The future standardisation of this part of the AD not only guarantees that the most relevant information reaches all types of audiences, but it also accelerates the elaboration process, as it serves as a guide for the research to be conducted prior to the writing of the script. The current ISO standard on AD (International Organization for Standardisation, 2015) only mentions $\mathrm{Al}$ as complementary content offered before the commencement of the AD itself. Therefore, this Al template also potentially improves the quality of such writing, allowing the professional audio describer more time to polish aesthetic and stylistic features, of high importance in a cultural event such as the opera. Moreover, it could also prove to be a very cost-effective method of Al productions, since a future standardisation could also make Als easier to share, and even translate, from opera house to opera house, therefore avoiding duplicated efforts.

The production of Al during the 2016/2017 season was made following this template. It has been used in 11 operas by the same audio describer. In practice, and from the audio describer's expertise, having a template has helped to identify the pieces of information that had to be extracted from all the materials prior to the issuance of the $A D$ script. The use of the template has also provided a common structure for every opera, not only for its live delivery but also for the addition of $\mathrm{Al}$ in the smartphone app that is being tested.

The presentation of a template for Al leads a path towards more research in this subject. Further testing of the effectiveness of this template in terms of a) production time, and b) end user satisfaction could be useful. A potential experiment would consist of inviting visually impaired users to an opera with an $\mathrm{Al}$ issued following the template and another with an $\mathrm{Al}$ issued without following the template. Likewise, during the production process, the audio describer could be monitored to establish whether the template makes the process easier.

\section{REFERENCES}

AENOR. (2005). Audiodescripción para personas con discapacidad visual. Requisitos para la audiodescripción y elaboración de audioguías (UNE 153020:2005). Retrieved from 
https://www.aenor.es/aenor/normas/normas/fichanorma.asp?codigo= N0032787\#.WQsnY1P5iqA

Benecke, B., \& Dosch, E. (2004). Wenn aus Bildern Worte werden. Durch Audio-Description zum Hörfilm. Munich: Bayerischer Rundfunk.

Braun, S. (2008). Audiodescription Research: State of the Art and Beyond. Translation Studies in the New Millennium, 6, 14-30. Retrieved from http://scholar.google.com/scholar?hl=de\&q=sabine+braun+audio+des cription\&btnG $=$ Suche\& $\mid r=\& a s \_y l o=\& a s \_v i s=0 \# 6$

Burton, J. (2008). The Joy of Opera: The Art and Craft of Opera Subtitling and Surtitling. In The Changing Face of Translation.' Proceedings of the 8th Portsmouth Translation Conference 2008: "The Changing Face of Translation (pp. 28-34). Portsmouth: University of Portsmouth. Retrieved from http://www.port.ac.uk/media/contacts-anddepartments/slas/events/tr08-burton.pdf

Cabeza, C. (2010). Opera audio description at Barcelona's Liceu theatre. In J. Díaz-Cintas, A. Matamala, \& J. Neves (Eds.), New Insights into Audiovisual Translaiton and Media Accessibility (pp. 227-238). Amsterdam: Rodopi.

Cabeza, C., \& Matamala, A. (2008). La audiodescripción de ópera: una nueva propuesta. In Á. Pérez-Ugena \& R. Vizcaíno-Laorga (Eds.), Ulises y la comunidad sorda (pp. 95-108). San Lorenzo del Escorial: Observatorio de las Realidades Sociales y de la Comunicación.

Cabeza i Cáceres, C. (2010). Opera audio description at Barcelona's Liceu theatre. In J. Díaz Cintas, A. Matamala, \& J. Neves (Eds.), New Insights into Audiovisual Translation and Media Accessibility (pp. 227-237). Amsterdam: Rodopi.

Corral, A., \& Lladó, R. (2011). Opera Multimodal Translation: Audio Describing Karol Szymanowski's Król Roger for the Liceu Theatre, Barcelona. The Journal of Specialised Translation, (15), 163-179. Retrieved from http://scholar.google.com/scholar?q=related:WUzz04RKQg8J:scholar. google.com/\&hl=en\&num $=30 \& a s \_s d t=0,5$

Di Giovanni, E. (2014). Audio introduction meets audio description: an Italian experiment. In R. M. Bollettieri Bosinelli, E. Di Giovanni, \& L. Rossato (Eds.), inTRAlinea Special Issue: Across Screens Across Boundaries. Retrieved from http://www.intralinea.org/specials/article/2072

Díaz Cintas, J., \& Anderman, G. (2009). The Wealth and Scope of Audiovisual Translation. In J. Díaz Cintas \& G. Anderman (Eds.), Audiovisual 
Translation: Language Transfer on Screen (pp. 1-17). Basingstoke: Pelgrave Macmillan.

Eardley-Weaver, S. (2014). Lifting the Curtain on Opera Translation and and Accessibility: Translating Opera for Audiences with Varying Sensory Ability. Durham University. Retrieved from http://etheses.dur.ac.uk/10590/

Fryer, L. (2010). Focusing attention: an experimental exploration of the relationship between sight loss and mental imagery (Unpublished PhD Thesis). University of London.

- (2016). An Introduction to Audio Description: A practical guide. London and New York: Routledge.

Fryer, L., \& Freeman, J. (2013). Visual impairment and presence. In H. Witchel (Ed.), Proceedings of the 2013 Inputs-Outputs Conference on An Interdisciplinary Conference on Engagement in $\mathrm{HCl}$ and Performance Inputs-Outputs '13 (pp. 1-5). New York, New York, USA: ACM Press. doi: $10.1145 / 2557595.2557599$

Griesel, Y. (2005). Surtitles and Translation: Towards an Integrative View of Theater Translation. MuTra 2005: Challenges of Multidimensional Translation, 62-75. $\quad$ Retrieved from http://translationconcepts.org/pdf/MuTra_2005_Proceedings.pdf\#page $=66$

Hammer, P., Mälzer, N., \& Wünsche, M. (2015). Audioeinführungen als Zusatzangebot zu Audiodeskriptionen? Trans-Kom, 8(1), 164-178. Retrieved from https://www.google.es/url?sa=t\&rct=j\&q=\&esrc=s\&source=web\&cd $=1$ \&ved=0ahUKEwiJpbnp_NXTAhVCPxQKHWqbCKQQFggmMAA\&url= http\%3A\%2F\%2Fwww.trans-kom.eu\%2Fbd08nr01\%2Ftrans-

kom_08_01_08_Hammer_Maelzer_Wuensche_Audioeinfuehrung.201 50717.pdf\&usg=AFQjCNḠkr2YpZz-BA_3hLs

Igareda, P., \& Matamala, A. (2012). Variations on the Pear Tree experiment: different variables, new results? Perspectives, 20(1), 103-123. doi: 10.1080/0907676X.2011.632684

Independent Television Commission (ITC). (2000). Guidance on Standards for Audio Description. Retrieved from http://stakeholders.ofcom.org.uk/broadcasting/guidance/otherguidance/tv_access_serv/archive/audio_description_stnds/ 
International Organization for Standardisation, \& International Electrotechnical Commission. (2015). Information technology - User interface component accessibility - Part 21: Guidance on audio descriptions (ISO/IEC TS 20071-21). Retrieved from https://www.iso.org/obp/ui/fr/\#iso:std:iso-iec:ts:20071:-21:ed-1:v1:en

Jankowska, A. (2013). Taking a British idea to Poland: Audio introductions for voiced-over films. In 4th Advanced Research Seminar on Audio Description (ARSAD) (13-14 March). Barcelona.

Kruger, J.-L., \& Orero, P. (2010). Audio description, audio narration - a new era in AVT. Perspectives, 18(3), 141-142. doi: 10.1080/0907676X.2010.487664

Matamala, A. (2005). Live audio description in Catalonia. Translating Today, 4(July), 9-11. Retrieved from https://www.researchgate.net/publication/283255751_Live_Audio_Des cription_in_Catalonia

- (2007). La audiodescripción en directo. In C. Jiménez Hurtado (Ed.), Traducción y accesibilidad: subtitulación para sordos y la audiodescripción para ciegos (pp. 121-132). Frankfurt am Main: Peter Lang.

Matamala, A., \& Orero, P. (2007). Accessible opera in Catalan: opera for all. In J. Díaz-Cintas, A. Remael, \& P. Orero (Eds.), Media for all: subtitling for the deaf, audio description, and sign language (pp. 201-214). Amsterdam: Rodopi.

Mateo, M. (2007). Surtitling today: New uses, attitudes and developments. Linguistica Antverpiensia, New Series - Themes in Translation Studies, 6, 135-154. Retrieved from:

https://lans-tts.uantwerpen.be/index.php/LANS-TTS/article/view/184

Orero, P. (2007a). Audiosubtitling: a possible solution for opera accessibility in Catalonia. Tradterm, 13, 135 . doi: 10.11606/issn.23179511.tradterm.2007.47470

- (2007b). Sampling audio description in Europe. In J. Díaz Cintas, P. Orero, \& A. Remael (Eds.), Media for all: subtitling for the deaf, audio description, and sign language (pp. 111-125). Amsterdam, New York: Rodopi.

Orero, P., Bestard, J., Edo, M., Iturregui-Gallardo, G., Matamala, A., \& Permuy Hércules de Solás, I. C. (n.d.). Opera accessibility in the 21st century: new services, new possibilities (1). 
Orero, P., \& Matamala, A. (2007). Accessible Opera: Overcoming Linguistic and Sensorial Barriers. Perspectives, 15(4), 262-277. doi: $10.1080 / 13670050802326766$

Palmer, J. (2013). Surtitling opera: a surtitler's perspective on making and breaking the rules. In Music, Text and Translation (pp. 21-34). London and New York: Bloomsbury Academic.

Puigdomènech, L., Matamala, A., \& Orero, P. (2008). The making of a protocol for opera audio description. Actas Del III Congreso Internacional de La Asociación Ibérica de Estudios de Traducción e Interpretación. La Traducción Del Futuro: Mediación Lingüístca y Cultural En EI Siglo XXI. Barcelona 22-24 de Marzo de 2007, 381-392.

Pujol, J., \& Orero, P. (2007). Audio description precursors: Ekphrasis, film narrators and radio journalists. Translation Watch Quarterly, 3(2), 49Retrieved from http://centresderecerca.uab.cat/caiac/content/audio-descriptionprecursors-ekphrasis-film-narrators-and-radio-journalists

Pylyshyn, Z. (2002). Mental imagery: in search of a theory. The Behavioral and Brain Sciences, 25(2), 157-82; discussion 182-237. doi: $10.1017 / \mathrm{S} 0140525 \mathrm{X} 02000043$

Ramos Caro, M. (2016). La traducción de los sentidos. Munich: LINCOM $\mathrm{GmbH}$.

Remael, A., \& Reviers, N. (2013). Combining introductions and Audio Description in Theatre. In 4th Advanced Research Seminar on Audio Description (ARSAD) (13-14 March). Barcelona.

Remael, A., Reviers, N., \& Vercauteren, G. (2014). ADLAB Audio Description guidelines. European Union under the Lifelong Learning Programme (LLP).

Reviers, N. (2014). Audio Introductions. In A. Remael, N. Reviers, \& G. Vercauteren (Eds.), Pictures Painted in Words, ADLAB Audio Description Guidelines.

Romero-Fresco, P., \& Fryer, L. (2014a). Audiointroductions. In A. Matamala, A. Maszerowska, \& P. Orero (Eds.), Audio Description: New Perspectives Illustrated (p. 216). John Benjamins Publishing Company. Retrieved

from https://books.google.com/books?id=TdjLBAAAQBAJ\&pgis=1 
- (2014b). Could Audio Described Films benefit from Audio Introductions? An Audience Response Study. Journal of Visual Impairment \& Blindness, 107(4), 287-295.

Walczak, A. (2017). Immersion in audio description (Unplublished PhD Thesis). Autonomous University of Barcelona.

Walczak, A., \& Fryer, L. (2017). Creative description: The impact of audio description style on presence in visually impaired audiences. British Journal of Visual Impairment, 35(1), 6-17. doi: $10.1177 / 0264619616661603$

- (2018). Vocal delivery of audio description by genre: measuring users' presence. Perspectives, 1-15. doi: 10.1080/0907676X.2017.1298634

Wijnants, J. (2014). Opera Surtitles: a New Text Between Libretto, Score, Translation, and Performance. In M. Cavagna \& C. Maeder (Eds.), Philology and Performing Arts: A Challenge (pp. 39-58). Louvain: Presses universitaires de Louvain.

York, G. (2007). Verdi made visible: audio introduction for opera and ballet. In J. Díaz Cintas, P. Orero, \& A. Remael (Eds.), Media for all: subtitling for the deaf, audio description, and sign language (pp. 215-230). Amsterdam: Rodopi. 